Portland State University

PDXScholar

\title{
Music and Ireland's National Identity: Connecting Folk Music and Cultural Theory through Emotional Sociology
}

Alexandra Habecker

Portland State University

Follow this and additional works at: https://pdxscholar.library.pdx.edu/honorstheses

Let us know how access to this document benefits you.

\section{Recommended Citation}

Habecker, Alexandra, "Music and Ireland's National Identity: Connecting Folk Music and Cultural Theory through Emotional Sociology" (2018). University Honors Theses. Paper 582.

https://doi.org/10.15760/honors.591

This Thesis is brought to you for free and open access. It has been accepted for inclusion in University Honors Theses by an authorized administrator of PDXScholar. Please contact us if we can make this document more accessible: pdxscholar@pdx.edu. 
Music and Ireland's National Identity:

Connecting Folk Music and Cultural Theory through Emotional Sociology

by

Alexandra Habecker

An undergraduate honors thesis submitted in partial fulfillment of the requirements for the degree of

Bachelor of Music

in

University Honors

and

Vocal Performance

Thesis Adviser

Jelena Simonovic Schiff

Portland State University

2018 


\begin{abstract}
Music has been a crucial component of every major social movement in history. Though studies have shown that music and other areas of the arts are a product of the surrounding world in response to their own historical context, I propose that music can and has directly impacted society through the effects of music on the human emotional response. By looking at cultural theory through a musicological lens and using Ireland's rich and rooted musical culture as an example, this thesis suggests that with further research into the connection between music and emotions, along with expanding interest in the growing field of emotional sociology, we can explain and identify the role of music as an agent of social change.
\end{abstract}




\section{Dedication}

This thesis is dedicated to my wonderful family who has supported me with strength and love when I thought of giving up.

To my great friends who listened to me ramble about Irish music for over a year and never complained once.

To Lucy, who stayed up with me until 4am editing, re-writing, and helping me keep my sanity on more than one occasion. 


\section{Table of Contents}

$\begin{array}{ll}\text { I. Introduction } & 4\end{array}$

II. Literature Review 5

$\begin{array}{lr}\text { III. Methodology } & 12\end{array}$

$\begin{array}{ll}\text { IV. The Irishness of Irish Music } & 13\end{array}$

$\begin{array}{lr}\text { V. Music, Emotions, and Society } & 18\end{array}$

$\begin{array}{ll}\text { VI. Conclusion } & 21\end{array}$

$\begin{array}{ll}\text { VII. Bibliography } & 23\end{array}$ 


\section{Introduction}

Music has the power to change the world. This is a sentiment that has been acknowledged by musicians, philosophers, and historians alike. Yet it is only in recent years that it has leaked into scientific discussion as well. Recent studies regarding the psychological and neurological effects of music have led to the establishment of new fields like music therapy. These studies and have given us concrete empirical data showing that music does indeed have an intrinsic effect on the brain. It is the purpose of this thesis to both promote and exemplify the significance of music on a personal and global scale. Developments in sociological studies reveal the correlation between human emotions and their interactions. By recognizing the effect of music on emotion, we open the door to a deeper understanding of music's impact on society.

Music has accompanied every major social movement in history. A prime example is the Civil Rights movement in the United States. Slave era spirituals and new compositions emerged as social statements and commentary on the events of the time. ${ }^{1}$ The liberation of Estonia, Latvia, and Lithuania is another powerful moment in music history. The events that took place in these countries between 1987-91 are known as "The Singing Revolution" due to the significant role choral music played in their non-violent revolution against Soviet rule. ${ }^{2}$ Instances of music playing a key part in social change are not aberrant, but are consistent in every area of the world throughout

\footnotetext{
${ }^{1}$ Katherine D. Power, "Musical Influence on Apartheid and the Civil Rights Movement" (Globalization Studies Capstone, Gettysburg College, 2014), 2-5.

2 The Singing Revolution, directed by James Tusty (Sky Films, 2006), DVD.
} 
history. This thesis will focus on the nation of Ireland, and the role music has played in its evolution as a country.

The national identity of Ireland is defined by a uniquely artistic cultural representation that emphasizes the importance of folk music. Even today people in Ireland will spontaneously begin to sing together in a way that surprises tourists. ${ }^{3}$ Because of folk music's degree of importance in Irish culture, this country is a prime candidate for observation. The first section of this thesis will provide historical context.

The second part will be devoted to the application of emotional sociology, a relatively new field of study, and to the musicological dissection of why Irish folk music is so culturally important and impactful to both performers and listeners. Discussions of the correlation between music and emotional response will be reviewed alongside emerging data neurological and psychological research. This thesis will connect these two academic realms, and promote understanding of the role of music as an agent for social change. Just as the world has changed music, music can and has changed the world.

\section{Literature Review}

\section{Historical Context}

Leslie Conran Corola's The Irish: A Treasury of Art and Literature ${ }^{4}$ is an impressive volume of Irish works dating from the ancient age up through the "Celtic

3 "Traditional Irish Music," Music and Theatre, Ireland, accessed April 8, 2018, https://www.ireland.com/en-us/events/music-and-theatre/traditional-music-and-dance/articles/trad-music/.

${ }^{4}$ Leslie Conran Corola, The Irish: A Treasury of Art and Literature (New York: Beaux Arts Editions, 1995). 
Revival" of the late 19 th and early 20 th centuries. This vast collection contains poems, song lyrics, short stories, and images of artwork representing every period in Ireland's history. The selection of works included in this volume were assembled to demonstrate either history in the making or the direct response to historical events. The introduction provides the reader with a brief but thorough overview of Irish history, and footnotes throughout the volume indicate the significance of each work in its historical context.

While Corola's book provides the reader with an overall sense of Irish culture, literature focused on specific time periods offers a more detailed picture of the place of Irish music in history. Two such books are David Greene's Irish Bardic Poetry 5 and George Sigerson's Bards of the Gael and Gall (Examples of the Poetic Literature of Erinn, Done into English after the Metres and Modes of the Gael) which both concentrate on the bardic era which existed from ancient Ireland through the Norman invasion. ${ }^{6}$ The bards were traveling storytellers and musicians, and it is to them we owe our earliest accounts of ancient Irish history and music. Bardic poetry was an essential part of Irish life as well as the foundation of Celtic music. Both Greene and Sigerson's collections of bardic poetry offer the original Gaelic alongside an English translation. They include information regarding the structure of these poems and briefly relay their historical importance to the reader. Through these collections we see the beginnings of a pattern of poetic content in Irish works, both musical and written.

The next significant movement in Ireland's music history was during the Jacobite rebellions. While the Williamite Jacobite War lasted from 1689-91, the rebellions and

${ }^{5}$ David Greene, Kelly Fergus, and Osborn Bergin, Irish Bardic Poetry (Dublin: Dublin Institute for Advanced Studies, 1970).

${ }^{6}$ George Sigerson Bards of the Gael and Gall: Examples of the Poetic Literature of Erinn, Done into English after the Metres and Modes of the Gael (New York: Scribner's Sons, 1907). 
uprisings of the Irish Scottish Jacobite armies against Great Britain's government army did not end until 1745 at the Battle of Culloden. It is during this violent period that Ireland, along with Scotland, fought to preserve their national identities in the face of English takeover. Much of today's Celtic music comes from this era and was later adapted and modified to fit other Irish political movements. John O'Daly's Reliques of Irish Jacobite Poetry ${ }^{7}$ captures the passion and purpose of poems and songs during this pivotal time. This book is a collection of poems, songs, stories, and historical accounts by Irish bards near the end of their existence. O'Daly has translated each piece from the original Gaelic. It is clear from his writings that O'Daly was an Irish nationalist who was one of many to romanticize the Jacobite cause.

Because of the ancient connection between music, poetry, and storytelling in Ireland's history, literature that discusses the role of Irish music specifically is rarer to find. A History of Irish Music by Chevalier William Henry Grattan Flood is possibly the greatest concise history of Irish music in its historical context. This is impressive given that it was written in 1905 and was the first of its kind. While many reviews point out his visible sympathies for the Jacobite rebels and Irish nationalist cause, this does not affect the facts presented in this work. As with O'Daly's collection, their bias against the English rule is to our favor, for it is their passion for Ireland and her music that is a key component of its importance in Ireland's cultural history.

Whereas both Flood and O'Daly's books were written in the wake of the the Jacobite rebellions during times of Irish political uncertainty, Gerry Smyth offers a more modern take with Music in Irish Cultural History. ${ }^{8}$ Unlike Flood, an early musicologist

\footnotetext{
7 John O'Daly, Reliques of Jacobite Poetry (Dublin: Samuel J. Machen, 1844).

${ }^{8}$ Gerry Smyth, Music in Irish Cultural History (Kildare: Irish Academic Press, 2009).
} 
whose focus was the effects of society and historical events on music, Smyth is a cultural historian first. His book looks more at the impact of music on Irish culture itself, and delves more into the cultivation of the Irish identity and the impact of its music through the ages.

Music, Emotional Sociology, and Cultural Theory

Sharri K. Hall's article "The Doctrine of Affections: Where Art Meets Reason" ${ }^{2}$ is perhaps the most well-known work to discuss the connection between music and emotion in the western world. Inspired by various doctrines of ethos from Ancient Greek philosophers, "The Doctrine of Affections" was a philosophical idea widely accepted during the Enlightenment and Baroque era. At the core of its argument was the belief that a composer could elicit certain emotional responses by using a specific musical formula. For example, a certain interval could evoke a feeling of joy in a listener, while a rough harmony combined with a rapid melody can instill a feeling of fury.

What Hall's article shows us is that the connection between music and emotion has been a topic among musical academics for some time. It has also been a subject of debate. Carl Dalhaus' book entitled The Ideas of Absolute Music provides us with a presentation of the conflicting philosophies of "absolute and program Music." In the most concise definition, absolute music is instrumental music that is composed purely for itself, and not meant to represent or illustrate anything else, specifically emotions. This idea appeared during the Romantic period in the seminal work by Eduard Hanslick, entitled Vom Musikalisch-Schönen (The Beautiful in Music, 1854). Dahlhaus describes

${ }^{9}$ Shari K. Hall, "The Doctrine of Affections: Where Art Meets Reason," Musical Offerings 8, no.2 (Fall 2017): 51-62, http://digitalcommons.cedarville.edu/musicalofferings/vol8/iss2/2. 
that the aesthetic of romanticism associated with absolute music was neither a theory of feeling or one of pure form. Instead of residing in one extreme or the other, absolute music lived somewhere in the middle as a "metaphysics of, variously, the sublime, soul, spirit, will, the infinite, the eternal, or the ineffable."10

The author or the 2013 article "Music and Emotions,"11 Piotr Przybysz, looks at contemporary research on music and emotions conducted at the "intersection of psychology, neuroscience and musicology." In the presented research he assumes that there is a close relationship between music and emotions, ranging from affective and emotional responses, to even physiological and behavioral reactions. Przybysz acknowledges absolute music and how absolutists believe that the aim of music is not to arouse feelings, though it does. He also presents us with empirical data from recent studies (to the publication date of this article) on how particular elements and features of music affect emotions. This research has been used in many budding scientific fields, such as music therapy. It suggests many different reasons for why music affects the human emotional experience, and even attempts to define exactly what emotions and emotional responses are. The main purpose of this paper, Przybysz states, is "to show that there are three areas of cognitive and behavioral activity of the listener and the respective types of musical emotions: embodied emotions, cognitive emotions, as well as associative and contextual emotions". ${ }^{12}$

10 J.L.H. Thomas, "Review: The Idea of Absolute Music by Carl Dahlhaus and Roger Lustig," Music \& Letters 72, no.1 (February 1991): 89-92, http://www.jstor.org/stable/736501.

${ }_{11}$ Piotr Przybysz, "Music and emotions," AVANT 4, no.3 (December 2013):176-178, http://przybysz[]amu.edu.pl.

12 lbid., 175. 
Studies regarding emotion on a sociological plane are not as common as one would think, given that it is a central dynamic in human behavior, interaction, and social organization. Three articles that discuss the impact of music on individual emotions are Peggy Thoits' "The Sociology of Emotions,"13 Nick Fox's "Emotions, Affects and the Production of Social Life,"14 and Jonathan Turner's "The Sociology of Emotions: Basic Theoretical Arguments." ${ }^{\prime 15}$ Each of these articles notes that, until recently, sociology has been primarily concerned with studying societies and their development on the macro level. Current studies on emotions are primarily focused on individual experiences and less so on their role in human interaction with others or various aspects of the human existence. Each of these scholarly works present different approaches on how studying emotions can be useful in understanding their role in shaping actions and capacities in many settings of sociological concern.

Turning then to look at music at a macro level, works describing music and its impact on society complete this literature review. The first is Music and Empathy, edited by Elaine King and Caroline Waddington. Along with prior philosophical attempts understand the extent of music's impact on human emotions and how it does so, this book is a collection of essays and studies regarding the connection between music and empathetic responses. Contributors to this work include leading scholars in fields of music psychology, neuroscience, music philosophy and education. Its argument is divided into two sections, looking both at the micro and macro levels of empathy and

\footnotetext{
${ }^{13}$ Peggy Thoits, "The Sociology of Emotion," Annual Review of Sociology 15 (1989): 3170342, http://jstor.org/stable/2083229.

14 Nick J. Fox, "Emotions, affects and the production of social life," The British Journal of Sociology 66, no. 2 (June 2014): 301-318.

15 Jonathan H. Turner, "The Sociology of Emotions: Basic Theoretical Arguments," Emotion Review 1, no.4 (October 2009): 340-354, http://emr.sagepub.com.
} 
musical engagement, meaning how individuals connect to musical stimulus versus how individual reactions affect the world around us.

John Shepherd and Peter Wicke's book entitled Music and Cultural Theory establishes a link between musicology and cultural studies, and is about processes and methods of operation of affect and meaning in music in wider cultural contexts. Their purpose is, as they describe it, "to feed musicology into cultural theory, to consider the implications for cultural theory of a viable theory for the social and cultural constitution of music as a particular and irreducible form of human expression and knowledge." In this book theories of culture, linguistics, structuralist, post-structuralist, and psychoanalysis are examined critically. ${ }^{16}$ Wicke and Shepherd's primary argument is that music is a central component of the cultivation of societies.

Olivier Urbain's collection of essays Music and Conflict Transformation: Harmonies and Dissonances in Geopolitics ${ }^{17}$ combines the micro and macro levels of emotional sociology with the use of music in cultural theory. The scholarly works in this volume demonstrate the power inherent in music to contribute in the most diverse manner to the process of healing. The essays are written by academics and experts in multiple fields, including the first essay written by Felicity Laurence, the author of the prologue to King and Waddington's own collection. The content varies from theoretical practice to case studies, and discusses the impact music can and has had on political climates as well as the way music can unify others, creating a sense of solidarity.

\footnotetext{
${ }^{16}$ John Shepherd, and Peter Wicke, Music and Cultural Theory (Massachusetts: Blackwell Publishers, 1997), 2-3.

17 Olivier Urbain, Music and Conflict Transformation: Harmonies and Dissonances in Geopolitics (London: IB Tauris in Association with the Toda Institute for Global Peace and Policy Research, 2008).
} 


\section{Methodology}

As previously stated, the primary aim of this thesis is to make a case for connecting the fields of musicology and emotional sociology to better understand the role of music in movements for social change. The research was entirely literature based, but included select musical recordings which serve as examples of the folk songs discussed. The field of musicology, which this thesis pertains to, embraces various disciplines surrounding its framework. This thesis combines Irish cultural studies with emotional sociology, philosophy, and music history, and the literature introduced in the review represents the broad discourse from each of these scholarly areas.

Because data compiled through research was purely qualitative, I utilized interpretive research methods. This thesis will be presented in two parts as there are two theoretical approaches to explore. In the first part, the historical and cultural interpretations of the effects of Irish folk songs are discussed. Since this study is looking at Irish music dating back to the ancient age of bards and minstrels, research directed at the cultural importance of music in Ireland through the ages is significant. The second part presents the theory that music can instill a feeling of solidarity and emotional connection between listeners and music makers alike and can evoke strong emotional responses that motivate individuals to action.

Perhaps the greatest challenge in compiling this literature review was that there is always more literature than one can possibly read. I read and reviewed what I could given the time constraints on this project and the limited resources granted, but with 
such a large discourse community and with the interest of looking at music through a cultural lens that is continuously growing in academia, I still wish I was able to read more. That being said, I like to think that this thesis is a prelude to further research I will conduct later in my academic career.

\section{The Irishness of Irish Music}

Folk music in Ireland has always been greatly valued and recognized as an essential component of Irish culture. Music is the first faculty of the Irish. It is their unique recognition of its importance that has set them apart. Ireland holds the firm belief that music has the inherent power to move people to action, and is the only country in the world that has chosen a musical instrument to be its national symbol: the Celtic harp. Thomas Davis, a $19^{\text {th }}$ century Irish writer, poet, and chief organizer of the nationalistic Young Ireland movement perfectly addresses this when he states, No enemy speaks slightingly of Irish Music, and no friend need fear to boast of it. It is without a rival. Its antique war-tunes, such as those of O'Byrne, O'Donnell, MacAlistrum and Brian Boru, stream and crash upon the ear like the warriors of a hundred lens meeting; and you are borne with them to battle, and they and you charge and struggle amid cries and battle-axes and stinging arrows. Did every a wail make man's marrow quiver and fill his nostrils with the breath of the grave, like the lulu of the North of the wirrasthrue of Munster?. ${ }^{18}$

The degree to which music is connected to Ireland's history is owed to the bards, Ireland's first historians. ${ }^{19}$ Bards were highly regarded poets, heralds, storytellers, and

18 W. H. Grattan Flood, A History of Irish Music (Dublin: Browne and Nolan, 1905), 1-2.

19 George Sigerson, Bards of the Gael and Gall: Examples of the Poetic Literature of Erinn, Done into English after the Metres and Modes of the Gael, (New York: Scribner's Sons, 1907), 2-6. 
musicians whose purpose was to pass down the histories and legends of Ireland in the oral tradition. They were trained by the Bardic Order at a college and kept as court musicians by Irish chiefs and later by wealthy English settlers. The Bardic Order existed until after the Norman invasion of the late 12th century which began more than 800 years of direct English rule. ${ }^{20}$ When the English arrived in the late Middle Ages and settled into their territory surrounding Dublin known as "The Pale," it was their goal to keep their civilized selves separate from the 'Irish barbarians' (this is where the phrase "beyond the Pale" originated). ${ }^{21}$ This goal backfired as the English settlers fell in love with the Irish way of life. King Edward III began to fear that the settlers were becoming more Irish than the Irish themselves. This lead to the passing of the Statute of Kilkenny in 1367 which set forth strict laws against acting Irish. A settler in the Pale could not marry an Irish person, could not adopt an Irish child, could not ride a horse in the Irish style (without a saddle), speak the Irish language, and so on. Among the many new laws was this:

$\mathrm{XV}$. Also, whereas the Irish agents who come amongst the English, spy out the secrets, plans, and policies of the English, whereby great evils have often resulted; it is agreed and forbidden, that any Irish agents, that is to say, pipers, story-tellers, bablers, rimers, mowers, nor any other Irish agent shall come amongst the English, and that no English shall receive or make gift to such; and that shall do so, and be attainted, shall be taken, and imprisoned, as well the Irish agents as the English who receive or give them any thing, and after that they shall make fine at the king's will; and the instruments of their agency shall forfeit to our lord the king. ${ }^{22}$

\footnotetext{
20 W.H. Grattan Flood, A History of Irish Music, 20-50.

${ }^{21}$ Leslie Conran Carola, The Irish: A Treasury of Art and Literature, (New York: Beaux Arts Editions, 1995), 116-119.

22 James Hardiman, "A Statute of the Fortieth Year of King Edward III., enacted in a parliament held in Kilkenny, A.D. 1367, before Lionel Duke of Clarence, Lord Lieutenant of Ireland," CELT: Corpus of Electronic Texts, University College of Cork, last modified 2011, https://celt.ucc.ie/published/T300001001.html.
} 
These laws were promptly ignored, and the Irish came up with various ways of expressing their indifference. Initially fines were put in place to discourage the hiring of Irish musicians although the patrons happily paid them. The fines were then applied to the bards, but the patrons' response was to pay their usual salary along with an extra amount for the fine. Later the English decided to place property fines, meaning plots of property would have to be paid to the crown. Even then the Irish would not back down, paying the bards their salary and additional plots of land so they could continue to perform. ${ }^{23}$

From hereafter, to sing in the Irish language or make music in the traditional Irish style became an act of defiance against the English government. This was not forgotten as England took more control over Ireland in the years following, and it is through the warring of these nations that we have a majority of the Irish music we hear today. Most familiar traditional Irish folk songs have stemmed from the Williamite War of 1689 - 1691 and the subsequent rebellions. The war began after the 'Glorious Revolution' of 1688 in which the Catholic King James II of England, Ireland, and VII of Scotland was deposed by the Protestant Prince William of Orange ${ }^{24}$ Anthems and ballads regarding the loss of their political and religious freedoms arose. Some were songs of mourning, such as "Mo Ghile Mear."25 The title translates to 'My Gallant Darling' and refers to Charles Edward Stuart, the grandson of King James II. Also known as 'The Young Pretender' and

${ }^{23}$ W. H. Grattan Flood, A History of Irish Music, 55.

24 Harman Murtagh, "The Williamite War 1689-91," History Ireland 1, no.1 (Spring 1993): 1-3, http://www.historyireland.com/penal-laws/the-williamite-war-1689-9111/.

25 UCD Choral Scholars, "Mo Ghile Mear," arranged by Desmond Earley, released December 11, 2015, track 1 on Invisible Stars: Choral Works of Ireland and Scotland, Signum Records, spotify streaming audio. 
'Bonnie Prince Charlie,' he led the Jacobite uprising of $1745 .{ }^{26}$ After his defeat at the battle of Culloden he escaped under secrecy and died in exile, effectively becoming a heroic figure for those who still believed in the Stuart cause. "Mo Ghile Mear" is written from the perspective of Ireland personified as the maiden goddess, Erinn. She is singing about her lost love and hero (Prince Charles) and of what has happened since he was sent away.

"Óró sé do bheatha bhaile" on the other hand is a song of victory. 'Óró' is a cheer while 'sé do bheatha bhaile' translates to 'welcome home'. The singers welcome home Prince Charles, saying in the last verse,

Young Charles is coming over the sea With French and Spanish volunteers. Armed and ready to protect him And they'll make the heretics dance! ${ }^{27}$

In a later version however, the lyrics are slightly altered so that the welcome is offered to Grace O'Malley (the $16^{\text {th }}$ century 'pirate queen of Ireland') instead of Prince Charles, by Patrick Pearse. He was an Irish nationalist leader, poet, educator, first president of the Irish republic, and commander in chief of the Irish forces in Easter Rising of 1916 for which 'Oro' was rewritten. The final verse of Pearse's version goes,

Grace O'Malley comes over the sea

With armed warriors at her guard

They're Irishmen - not French or Spanish

And they will rout the foreigners! $!^{28}$

26 "Charles Edward, the Young Pretender," Encyclopaedia Brittanica, last modified 2018, http://www.brittanica.com/biography/Charles-Edward-the-Young-Pretender.

27 "English Translations of Oro se de beatha "bhaile," Irish Music Daily, last modified 2018, http://www.irishmusicdaily.com/oro-se-do-bheatha-bhaile-translation.

28 "Patrick Pearse, Irish Poet and Statesman," Encyclopaedia Brittanica, last modified May 1, 2018, https://www.britannica.com/biography/Patrick-Henry-Pearse. 
It was common for pieces like 'Mo Ghile Mear' and 'Oro' to be used as protest songs through the political revolution of the early $20^{\text {th }}$ century. Some, like "The Minstrel Boy" didn't need to be edited for it already articulated the emotions and political struggles of the time. The second to last verse sings,

The minstrel boy to the war is gone, In the ranks of death ye may find him; His father's sword he hath girded on, With his wild harp slung along behind him; Land of Song, the lays of the warrior bard, May someday sound for thee, But his harp belongs to the brave and free And shall never sound in slavery! ${ }^{29}$

There was more than just political protest and angry defiance to the folk music of this era, however. Even today after the declaration of the Republic of Ireland these songs remain prevalent. The Bloody Irish is a modern musical about the 1916 Easter Uprising and is comprised of traditional folk songs, including "The Minstrel Boy," "Mo Ghile Mear," and "Oro."30

Irish Cultural Historian Gerry Smyth writes,

Music was both a private, affective action and a public, social ritual whereby the subject could 'perform' their Irish identity, fired by the belief that each individual musical act - be it a composition or a performance or simply listening to a piece of music - was in some way part of an ancient, ongoing tradition which confirmed (and, with each new act, reconfirmed) the validity of both the individual and the nation. ${ }^{31}$

${ }^{29}$ Benjamin Britten, "The Minstrel Boy," arranged by Graham Johnson, released March 1, 2005, track 4 on disc 2 of Folk Song Arrangements (English Song Vol. 10), Naxos 8.557220-21.

30 D. Downes, "The Minstrel Boy," "Mo ghile mear," and "oro se do bheatha "bhaile," released January 15, 2016, tracks $7 \& 8$ on disc 1 and 8 on disc 2 from The Bloody Irish, Naxos, Sony Classical 886445490671.

${ }_{31}$ Gerry Smyth, Music in Irish Cultural History (Kildare: Irish Academic Press, 2009), 2-4. 
These songs vindicated Irish culture in support of a politically valid modern nation and still do. To perform these songs is an affirmation of one's cultural heritage and identity as well as a reminder of all that has been lost and gained. Folk music has seeped its way into the foundation of Ireland's national identity for all that it symbolizes and the emotions that it evokes.

\section{Music, Emotions, and Society}

The connection between music and emotion has been a topic of discussion for centuries. It was understood by ancient Greek philosophers that music evokes emotional response from both performers and listeners. Various doctrines of ethos were put forth and eventually inspired the Baroque era's "Doctrine of Affections." It stated that music had a physical power; that emotions could be represented and elicited through specific figurations of music, and that they could alter the four body "humors" to remedy illness and imbalance. ${ }^{32}$

The Greeks and other early music philosophers examined the effects of music on a more formulaic and intrinsic level, attempting to explain a deeper purpose for music mathematically. Philosophers in the $18^{\text {th }}$ century tried to understand music's ability to 'depict the motions of nature of the human soul'. The Romantics later explored the concept of "absolute music." Philosophers and musicologists throughout the ages are

${ }^{32}$ Sharri K. Hall, "The Doctrine of Affections: Where Art Meets Reason," Musical Offerings 8, no. 2 (Fall 2017): 51-62. 
continuously working to understand the reason within music and its effect on humanity. It is only recently that the sciences have taken an interest in this sociological factor. ${ }^{33}$ Music therapy is a relatively new field that uses studies of music from a neurological and psychological standpoint to find ways of using music in therapeutic applications. It is used to treat those with dementia, Alzheimer's, autism, PTSD, and other disorders both psychological and otherwise.$^{34}$ Music therapy has been focused on neurological responses to music in the individual, but little has been to apply these findings to a broader context. For example, there is a new theory put forward by composer, director, and musicologist Felicity Laurence that states that the action of making music elicits an empathic response between performer and listener. ${ }^{35}$ The ability for music to trigger empathy can explain the feeling of 'oneness' and solidarity that is found when people sing together. Empathy as a means of understanding an array of psychological aberrance is a phenomenon that is only just beginning to be explored in music therapy. Laurence is currently working on a project based in the Middle East investigating practices and dilemmas in music to alleviate profound political conflict there. ${ }^{36}$

The effect of emotion on society has not been explored much within the Sociological field. Emotions are an essential component of human behavior and more work needs to be done at the micro-level of analysis. Emotion has historically been

33 J. L. H. Thomas, "Review: The Idea of Absolute Music by Carl Dahlhaus and Roger Lustig," Oxford University Press (1991): 89-92.

34 "Music Therapy with Specific Populations: Fact Sheets, Resources, \& Bibliographies," American Musical Therapy Association, last updated 2018, https://musictherapy.org/research/factsheets/.

${ }^{35}$ Elaine King and Caroline Waddington, Music and Empathy (New York: Routledge, 2017), 1-35. laurence/.

36 "Felicity Laurence" RNCM, last updated 2018, https://www.rncm.ac.uk/people/felicity- 
regarded as the dependent variable, but its role as an active intervening variable in social processes is beginning to take a stronger hold. There is little known about the "distribution of emotional experiences in the population," 37 (i.e. the emotional interactions, emotional socialization processes, and the relationships between social structure and emotional norms.) There are many new theories regarding sociological approaches to emotions that have helped to explain some emotional dynamics. There are unresolved issues surrounding the nature of emotions, the degree to which they are neurologically hard-wired or socially constructed, and the impact of emotions on surrounding society..$^{38}$ Ultimately more empirical research is needed to support these growing theories. It is then, with the data collected, we can begin to include a more definitive discussion of music and cultural theory.

It is not purely the artist who creates art, but the ever-present influence of the world as well. William Shakespeare wrote, "For anything so overdone is from the purpose of playing, whose end, both at the first and now, was and is to hold, as 'twere, the mirror up to nature, to show virtue her own feature, scorn her own image, and the very age and body of the time his form and pressure." ${ }^{39}$ Holding a mirror up to the world is part of art's purpose as a product of society. However, in holding up the mirror and reflecting the image, society is thus affected and in turn becomes a product of the art. Music's social character therefore flows as much from its contribution to social process

${ }^{37}$ Peggy A. Thoits, "The Sociology of Emotions", Annual Review of Sociology 15, (1989): 317318.

38 Jonathan $\mathrm{H}$. Turner, "The Sociology of Emotions: Basic Theoretical Arguments", Emotional Review 1, no. 4, (2009): 340-354. 2008.

39 William Shakespeare, Hamlet, edited by George Richard Hibbard, Oxford University Press: 
as it does from its capacity to symbolize them. Music is "central rather than peripheral" to people and society. ${ }^{40}$

\section{Conclusion}

The role of folk music in understanding global cultures, the scope of the connection between music and emotional response, and the degree to which emotions affect society are all subjects that require more attention and observation. Results gained could be applied to understanding music's full impact on society and aid in the understanding of a culture's entire identity, as it has in Ireland. Further research will provide sound empirical data supporting the theory that eliciting an emotional response directly influences human behavior and societal structure and that emotion can be triggered by music. Music affects emotions which affect society which then in turn affects the music. The musical history of Ireland provides the exemplary echo of this theory, thinking back to how traditional folk song was used to rally a nation in solidarity.

The theories and data that will arise from the research discussed in this thesis will aid us in furthering our understanding of music as an agent for social change and music's role in other cultures. Emotional response is not unique to one part of the world, and music has built bridges between people of all backgrounds since the beginning. Though it may sound ideological, more research into the correlation between music and emotion could realistically provide the key to a new approach to foreign diplomatic relations. It could lay the groundwork for a universal language dedicated to a unification

\footnotetext{
40 John Shepherd and Peter Wicke, Music and Cultural Theory (Massachusetts: Blackwell Publishers, 1997), 3-4.
} 
and resolution of geopolitical conflicts. The understanding of the absolute impact of music is growing and with it comes a great unity. Through our own emotional experience music affects our actions. In this way music changes the individual. The individual is both a reflection and refraction of these responses. Music changes the individual. Music ignites change. Music can change the world. 


\section{Bibliography}

American Musical Therapy Association. "Music Therapy with Specific Populations: Fact Sheets, Resources, \& Bibliographies." Last updated 2018. https://musictherapy.org/research/factsheets/.

Britten, Benjamin. "The Minstrel Boy." Arr. by Graham Johnson. Folk Song Arrangements (English Song Vol. 10), Naxos 8.557220-21.

Carola, Leslie Conran. The Irish: A Treasury of Art and Literature. New York: Beaux Arts Editions, 1995.

"Charles Edward, the Young Pretender." Enclyclopaedia Brittanica. Last modified 2018. http://www.brittanica.com/biography/Charles-Edward-the-Young-Pretender.

Downes, D.. "The Minstrel Boy," "Mo ghile mear," and "Oro se do bheatha 'bhaile." The Bloody Irish, Sony Classical 886445490671

"English Translations of Oro se do bheatha "bhaile." Irish Music Daily. Last updated 2018.

http://www.irishmusicdaily.com/oro-se-do-bheatha-bhaile-translation.

Flood, W.H. Grattan. A History of Irish Music. Dublin: Browne and Nolan, 1905.

Fox, Nick. "Emotions, affects and the production of social life." The British Journal of Sociology 66, no. 22 (2015): 301-318.

Greene, David, Kelly Fergus, and Osborn Bergin. Irish Bardic Poetry. Dublin: Dublin Institute for Advanced Studies, 1970.

Hall, Sharri K.. "The Doctrine of Affections: Where Art Meets Reason." Musical Offerings 8, no. 2 (2017): 51-64.

Hardiman, James. "A Statute of the Fortieth Year of King Edward III., enacted in a parliament held in Kilkenny A.D. 1367, before Lionel Duke of Clarence, Lord Lieutenant of Ireland." CELT: Corpus of Electronic Texts. University College of Cork. Last modified 2011. https://celt.ucc.ie/published/T300001-001.html.

Ireland. "Traditional Irish Music." Music and Theatre. Accessed April 8, 2018. https://www.ireland.com/en-us/events/music-and-theatre/traditional-music-anddance/articles/trad-music/.

King, Elaine and Caroline Waddington, Music and Empathy, New York: Routledge, 2017. 
Murtagh, Harman. "The Williamite War 1689-91." History Ireland 1, no. 1 (Spring 1993): 1-3. http://www.historyireland.com/penal-laws/the-williamite-war-1689-9111/.

O'Daly, John. Reliques of Irish Jacobite Poetry. Dublin: Samuel J. Machen, 1844.

"Patrick Pearse, Irish Poet and Statesman." Encyclopaedia Brittanica. Last modified May 1, 2018. https://www.brittannica.com/biography/Patrick-Henry-Pearse.

Pittock, Murray G.H.. Poetry and Jacobite Politics in Eighteenth-century Britain and Ireland. New York: Cambridge University Press, 1994.

Power, Katherine D.. "Musical Influence on Apartheid and the Civil Rights Movement." Globalization Studies Capstone, Gettysburg College, 2014.

Przybysz, Piotr. "Music and Emotions" AVANT 4, no. 3 (2013): 175-196.

Shakespeare, William. Hamlet. Edited by George Richard Hibbard. Oxford: Oxford University Press, 2008.

Shepherd, John and Peter Wicke. Music and Cultural Theory. Massachusetts: Blackwell Publishers, 1997.

Sigerson, George. Bards of the Gael and Gall: Examples of the Poetic Literature of Erinn, Done into English after the Metres and Modes of the Gael. New York: Scribner's Sons, 1907.

Smyth, Gerry. Music in Irish Cultural History. Kildare: Irish Academic Press, 2009.

The Singing Revolution. Directed by James Tusty. Sky Films, 2006. 1hr. 37 min. DVD.

Thomas, J. L. H.. "Review: The Idea of Absolute Music by Carl Dahlhaus and Roger Lustig," Oxford University Press, Music and Letters 72, no. 1 (1991): 89-92.

Thoits, Peggy A.. "The Sociology of Emotions." Annual Review of Sociology 15, (1989): 317-342.

Turner, Jonathan H.. "The Sociology of Emotions: Basic Theoretical Arguments." Emotion Review 1, no. 4 (2009): 340-354.

UCD Choral Scholars. "Mo Ghile Mear." Arr. by Desmond Earley. Invisible Stars: Choral Works of Ireland and Scotland. Signum Records, spotify streaming audio.

Urbain, Olivier, Music and Conflict Transformation: Harmonies and Dissonances in Geopolitics. London: I.B. Tauris in Association with the Toda Institute for Global Peace and Policy Research, 2008. 